\title{
Another Type of Character Education: Citizenship Education
}

\author{
Nur Silay ${ }^{1, *}$ \\ ${ }^{1}$ English Language Center, Koç University, Rumelifeneri Yolu, 34450, Sarıyer, İstanbul, \\ Turkey \\ *Correspondence: Tel: 90-532-232-8340 E-mail: nur.silay@gmail.com
}

Received: January 20, 2014

Accepted: April 1, 2014 Published: April 22, 2014

doi:10.5296/ije.v6i2.4949

URL: http://dx.doi.org/10.5296/ije.v6i2.4949

\begin{abstract}
The purpose of this paper is to share one specific section in the literature review of a doctoral dissertation. This paper aims at presenting research findings by different researchers and enabling readers to see an overview of an educational current called "citizenship education". The concept of citizenship is connected with democratic values and an ideal citizen is not only an individual who knows much about politics, but also an active person who takes a responsible role in the daily, political life of their society. Citizenship education especially takes place at schools as a policy of the state and students are encouraged and trained to take part in the societal activities of the community they live in. Citizenship education and character education are similar in many ways and citizenship education is considered as a type of character education by some scientists. Some of these similarities include the reason why they emerged, the fact that both are connected to the core values, their close relationship with moral education, common identical methods they use, and sharing some positive character traits. To conclude, these two educational currents are alike in several respects and they complement each other. It must also be mentioned that it is important to offer both educational currents to students not only for the benefit of the individuals, but also for the benefit of the whole society and the future.
\end{abstract}

Keywords: citizenship education, character education, community service learning 


\section{Introduction}

Citizenship education is an educational current that has received a high degree of attention along with character education. These two approaches have many common aspects as well as moral education and values education. Several researches have been conducted and the implementation of citizenship education has been taking place in many educational institutions. This paper intends to gather different research findings from various sources and evaluate them by comparing the findings and reaching a synthesis. This is a research review which was included as one of the in-depth sub-sections in the literature review of the author's doctoral dissertation. The intention of the author is to unveil some key parts of her dissertation as the dissertation is available only to speakers of her native language, which is spoken solely in one country.

Below, some definitions of "research review" have been provided by local and foreign scientists. According to Ayşan, the aim of reviews is compiling information about a topic and offering readers that information in a meaningful and chronological way. Hence, the past and present situations as well as future research studies on that topic are presented (Ayşan, 2003). Creswell explains that syntheses of past research first mention the problem, then identify the central theme, and lastly identify the major conclusions (Creswell, 1994). He calls this type of nonempirical study "review" and not research study. Robson defines research review as "having a synoptic aim of putting together and evaluating different kinds of findings in a particular field of interest" (Robson, 2000). Since the objective is collecting and then assessing diverse types of research findings, this paper should be considered a research review (Robson, 2000).

\section{The Concept of Citizenship}

It seems appropriate to remember the responsibilities of a good citizen so as to comprehend the concept of "citizenship". According to Haynes et al, "the citizen must demonstrate a reasoned commitment to fundamental principles, such as popular sovereignty, rule of law, religious liberty, and the like". In their opinion, good citizens must also show a clear attachment to core values, such as freedom, life, equality, following happiness, the quality of being true, and encouragement of the common good (Haynes et al, 1997). Therefore, a responsible citizen needs to show commitment both to principles and values. The above-mentioned authors think that religious freedom is among basic principles whereas equality is considered one of the most important values. Westheimer and Kahne state that "conceptions of good citizenship imply conceptions of the good society" (Westheimer \& Kahne, 2004). In Westheimer and Kahne's opinion, personal responsibility receives the most attention among conceptions of citizenship and democratic values. Here, the authors draw attention to the direct link between the society and citizenship in terms of goodness. They also mention the relationship between the concepts of citizenship and democracy and emphasize the significance of responsibility. Hence, it could be well deduced that good citizenship necessitates a democratic environment and the existence of values is vital for responsible and good citizens. 
Sax reports that there are three attitudinal and behavioral aspects of citizenship: commitment to social activism, sense of empowerment, and community involvement (Sax, 2004). For the first one, the author lists certain life goals such as "participating in community action programs, helping others who are in difficulty, influencing social values, and influencing the political structure." The second one means the level of feeling about how much an individual can do to bring changes in society. The last one is about engagement in voluntary work or community service. Similarly, McLaughlin expresses the three elements of citizenship as "social and moral responsibility, community involvement, and political literacy" (McLaughlin, 2000). It is understood that both authors seem to agree on the qualities of citizenship. They stress the importance of feeling responsible, being active, and taking part in serving the community voluntarily. It is vital that a good citizen is not somebody who knows a lot about politics and stays passive. In order to be regarded as a really "good" citizen, one has to play an active role in society by becoming a "doer" instead of a "watcher".

Arthur and Davison define citizenship in two dimensions: passive and active (Arthur \& Davison, 2000). The former involves knowing, understanding, and behaving within the context of participation in democracy. The latter one; however, adds empowerment by improving criticality so that citizens could question, critique, debate, and become a leader. The authors also name the second one "powerful citizenship". Arthur and Davidson appear to echo Sax and McLaughlin in this respect. The active citizen is an individual who criticizes unlike the passive one. The participation of citizens is crucial for the well-being of a society. Hence, once again, the inactive existence of people is not desired. In contrast, responsible citizens who are willing to change things for the better, who are actually taking part in the activities for the benefit of the whole society, who are spending both time and effort so as to improve the whole community are needed for effective and democratic citizenship.

Hoge states that the unique demands of citizenship are advanced values education tasks and these tasks are directly related to the full and powerful exercise of citizenship (Hoge, 2002). The examples for such tasks are "developing allegiance to the state and nation, inspecting the morality and allegiances of candidates for public office, becoming adept at conducting a values centered analysis of public issues, developing a strong commitment to defending the civil rights of minorities, and gaining skill in advocating government policies that balance the interests of opposing parties". It may be seen that the list has the necessary qualities peculiar to citizenship values. They are all directly connected to the requirements of being an exemplary citizen. Lastly, the essential link with morals is also visible within the context of candidates for public sector.

\section{The Characteristics of Citizenship Education}

In Hoge's opinion, the definition of citizenship education is "any conscious or overt effort to develop students' knowledge of government, law, and politics as those have evolved through history and presently operate in their society" (Hoge, 2002). He mentions that the aim of citizenship educators is how to make good people become involved constructively with the continuous development of their democratic society. Therefore, this definition focuses on the 
development of knowledge whereas educators strive to push good people into action in their own society. It is obvious that such educators work on getting those people take part in the activities of society.

According to popular communitarians, schools should increase moral character and a sense of responsibility, which could assist students to act morally and civilly (Arthur, 1998). Arthur reports that "There is clearly a strong concern for values and morality in communitarian thought and an emphasis on education for citizenship and a desire to identify the shared core values that can be taught". In his opinion, British communitarians encourage schools to take values seriously as "values are part of everyday life and are experienced and taken for granted through action." Therefore, it is obvious that Arthur sees a connection between citizenship education and moral values. For him, one of the characteristics of citizenship education is to enable students to act with values. It must be kept in mind that the values he means are those that are shared by the community and that are the most basic and important values. Some examples of such values include family values, social identity, being responsible and caring individuals.

Arthur and Davison (2000) present a distinction between their concepts of normative and individualistic citizenship and between active and passive citizenship in order to highlight the beliefs and values which may be regarded as typifying four versions of citizenship in Table 1: Paleoconservative, communitarian, libertine, and libertarian versions.

Table 1. Versions of citizenship

\section{NORMATIVE / COMMUNAL}

\begin{tabular}{|c|c|c|c|}
\hline & $\begin{array}{l}\text { Paleoconservative } \\
\text { traditional } \\
\text { loyal } \\
\text { family } \\
\text { parochialism } \\
\text { fraternal } \\
\text { moral }\end{array}$ & $\begin{array}{l}\text { Communitarian } \\
\text { collectivism } \\
\text { democracy } \\
\text { service } \\
\text { collaboration } \\
\text { altruism } \\
\text { sense of community }\end{array}$ & A CTIVE \\
\hline PASSIVE & $\begin{array}{l}\text { individualism } \\
\text { materialism } \\
\text { permissive } \\
\text { hedonism } \\
\text { apolitical } \\
\text { Libertine }\end{array}$ & $\begin{array}{l}\text { market forces } \\
\text { pro-enterprise } \\
\text { elitism } \\
\text { meritocratic } \\
\text { utilitarian } \\
\text { Libertarian }\end{array}$ & \\
\hline & PRAGN & INDIVIDUALISTIC & \\
\hline
\end{tabular}

Arthur, J. \& Davison, J. (2000). Social literacy and citizenship education in the school curriculum, page 15 
Arthur and Davison state that for the paleoconservative version, citizenship education would mainly be about "complying with various kinds of authority". This kind of citizenship education would encourage responsibility, respect, self-discipline, submission, conformity, and docility. The authors describe communitarian citizenship education as "emphasizing the role of mediating social institutions in addition to schools, in the belief that society as a whole is educative". They explain that libertine citizenship education would be involved in a continuous effort to make sure the highest independence for each person with everything up for argument and questioning. Lastly, libertarian citizenship education at best could be on improving a student's "competence to operate successfully within the capitalist system and to understand the rules and develop the dispositions of utilitarian creativity and entrepreneurial drive" (Arthur \& Davison, 2000).

\section{Similar Qualities between Citizenship Education and Character Education}

Character education may simply be defined as fostering the development of character in children and also students (Howard et al, 2004). In other words, it is an encouragement so as to improve the character of young people. Character education and citizenship education have a lot of similarities. Researchers have found many likenesses between the two educational currents and some of these common characteristics are as follows.

One similarity between citizenship education and character education is that, both are related to "a perception of a crisis in society" (Davies et al, 2005). In other words, the origin of these approaches is alike. Both emerged because of the needs of society. Davies et al explain that crisis was a key feature of the status of citizenship education in the early 1990s. Likewise, they point out that some important personalities in the improvement of character education draw attention to problems in society. Among other similarities which they mention are their relationship with moral issues, the fact that both are broadly characterized, and some common ideas about styles of learning and teaching. Regarding the last similarity, Davies et al express that citizenship education emphasizes the significance of classroom climate (Davies et al, 2005). Similarly, there is research evidence "to suggest that methods appropriate for democracy are effective." It may be interpreted that classroom climate has an important impact on students' learning and also democratic methods in the classroom have a positive influence on learning for both character education and citizenship education.

An additional likeness is that both programs intend "to encourage children to appreciate, and sympathize with, a common approach to values" (Revell, 2002). Revell also mentions that both of them are able to exert influence on children. Moreover, the author argues that children's understanding of the content of citizenship education or character education lies within the context of pre-existing beliefs about citizenship or character. In her opinion, "the values children are taught or see modelled at school are mediated with the values and beliefs they have assimilated through contact with their parents, peers or other groups" (Revell, 2002). Therefore, it is understood that both educational currents are related to values and both are influential on students. 
Below, there is Table 2, which shows a partial taxonomy of character education programs that concentrate on citizenship. The total number of types of character education programs is ten as Howard et al (2004) indicate and three of these types are involved in citizenship education.

Table 2. Partial taxonomy of character education programs focusing on citizenship

\begin{tabular}{|c|c|c|}
\hline Type & $\begin{array}{c}\text { Major pedagogical } \\
\text { approach }\end{array}$ & Example \\
\hline Service-learning & $\begin{array}{l}\text { "Hands-on" experiences } \\
\text { of community service } \\
\text { integrated into the } \\
\text { curriculum }\end{array}$ & $\begin{array}{l}\text { Community service-learning (e.g., } \\
\text { Born, 1999; Kielsmeier, 2000; Wade, } \\
\text { 1997, 2000) }\end{array}$ \\
\hline $\begin{array}{l}\text { Citizenship } \\
\text { training - } \\
\text { Civics education }\end{array}$ & $\begin{array}{l}\text { American civic values } \\
\text { taught as a preparation } \\
\text { for future citizenship }\end{array}$ & $\begin{array}{l}\text { We the People (from the Constitutional } \\
\text { Rights Foundation) }\end{array}$ \\
\hline Caring community & $\begin{array}{l}\text { Caring relationships } \\
\text { fostered in the } \\
\text { classroom and school }\end{array}$ & $\begin{array}{l}\text { Child Development Project (1996) } \\
\text { (from the Developmental Studies } \\
\text { Center); Community of Caring (from } \\
\text { the Joseph P. Kennedy Jr. Foundation); } \\
\text { Educating Moral People (Noddings, } \\
\text { 2002a) }\end{array}$ \\
\hline
\end{tabular}

Howard et al. (2004) Politics of character education, page 197

According to Howard et al, service learning is among the strategies to encourage democratic dispositions and citizenship education consists of dispositions, skills, and knowledge (Howard et al, 2004). For instance, “teaching immigrants the answers to the United States's test for citizenship is both a service and a way for students themselves to know the content". Another example is providing a résumé service to homeless and unemployed people as service-learning. The first example also falls under the category of citizenship training and civics education as the American civic values are taught as a preparation for the desired citizenship.

Howard et al also report that "many of the prescriptions of caring character education are found in practicing Just Communities. Notably, they share constructivist approaches, an emphasis on relationships, and using, addressing, and resolving real ethical dilemmas that arise in community to promote character development" (Howard et al, 2004).

It has been mentioned above that Table 2 shows those types of character education that concentrate on citizenship education. Therefore, it is comprehended that citizenship education is regarded as one of the kinds of character education in Howard et al's eyes. In short, they see character education as a comprehensive educational current which includes citizenship education.

In Hoge's opinion, “citizenship education actually needs a character education foundation" 
(Hoge, 2002). The author thinks that the former builds on and increases "the basic moral reflexes engrained by effective character education". In Table 3, a comparison of these two approaches by Hoge can be seen. The left column shows the eight foci of comparison.

Table 3. Comparison of character and citizenship education

\begin{tabular}{|c|c|c|}
\hline Comparison focus & Character Education & Citizenship Education \\
\hline Central concern & Improved people & Improved government \\
\hline Content taught & Character traits and values & $\begin{array}{l}\text { Knowledge of government, law, } \\
\text { and politics }\end{array}$ \\
\hline Pre-eminent values & $\begin{array}{l}\text { Responsibility; respect for } \\
\text { self and others; honesty; } \\
\text { kindness/caring; fairness; } \\
\text { cooperation }\end{array}$ & $\begin{array}{l}\text { Freedom; equality; legal rights; } \\
\text { justice; citizen participation; } \\
\text { patriotism; respect for diversity, } \\
\text { authority, property and privacy }\end{array}$ \\
\hline Fears & $\begin{array}{l}\text { Bad people; loss of } \\
\text { traditional moral standards }\end{array}$ & $\begin{array}{l}\text { Bad government; loss of freedom } \\
\text { and rights }\end{array}$ \\
\hline $\begin{array}{l}\text { Instructional } \\
\text { concern }\end{array}$ & $\begin{array}{l}\text { The internalization of } \\
\text { established prosocial values }\end{array}$ & $\begin{array}{l}\text { The acquisition of citizenship } \\
\text { knowledge and skills }\end{array}$ \\
\hline Instructional focus & $\begin{array}{l}\text { Individuals; personal } \\
\text { behavior }\end{array}$ & Society; social problems \\
\hline $\begin{array}{l}\text { Areas of } \\
\text { implementation } \\
\text { and advocates }\end{array}$ & $\begin{array}{l}\text { Implemented mostly in } \\
\text { elementary; advocates are a } \\
\text { diverse group of educators } \\
\text { who embrace the need for } \\
\text { character education }\end{array}$ & $\begin{array}{l}\text { Implemented mostly in middle and } \\
\text { high schools; advocates are social } \\
\text { studies educators, who have } \\
\text { assumed citizenship education } \\
\text { responsibilities }\end{array}$ \\
\hline $\begin{array}{l}\text { Dominant } \\
\text { instructional } \\
\text { methods }\end{array}$ & $\begin{array}{l}\text { Trait-of-the-week } \\
\text { instruction; slogans; } \\
\text { instructive biography; } \\
\text { rewards programs }\end{array}$ & $\begin{array}{l}\text { Direct instruction on government, } \\
\text { law, and politics; issues-based } \\
\text { discussions; mock trials and field } \\
\text { trips }\end{array}$ \\
\hline
\end{tabular}

Hoge, J. D. (2002) Character education, citizenship education, and the social studies, page 106

Hoge also adds that "the substantial differences between the predominate practices of character education and citizenship education may be viewed as complementary in that instruction emanating from one perspective need not preclude instruction from the other" (Hoge, 2002). Moreover, he argues that a good democratic government heavily depends on an informed, virtuous, and involved public.

Milson and Chu believe that in the context of civic education and social studies, character education takes the shape of improving civic virtue. The civic virtue is the virtuous behavior that provides the right conditions for citizenship (Milson \& Chu, 2002). In their opinion, "a citizen must develop civic commitments to democratic values and principles as rule of law, popular sovereignty, liberty, justice, and equality". Again, values and virtues have been 
mentioned and the direct link between the two educational currents has been highlighted.

According to Anderson, educators would like students to become experienced in a wide range of ideas and productive citizens; hence, while planning effective teaching strategies, they need to join the research-based knowledge which will include the strengthening of character education (Anderson, 2000). The author thinks that "students should be provided hands-on learning experiences that apply directly to life skills, which can be offered through classroom and community service projects that allow students to practice responsible leadership skills". As a result, she concludes that such experiences will consolidate positive social behavior and improve necessary citizenship skills. She finally states that "professional educators should emulate character traits such as integrity, courage, trustworthiness, and compassion". It is clearly seen that some character traits are vital for ideal citizenship. Like the former authors, she repeats the necessity of service learning for the benefit of society, leading to acquiring responsibility. The end result will be becoming responsible and productive citizens in the future.

\section{Conclusion}

So as to think about citizenship education and see the similarities between character education and citizenship education, one needs to start by remembering the characteristics of a citizen. In other words, revising the meaning of citizenship and recalling the qualities of an ideal citizen are essential before moving on to the next step. Good citizens are those individuals laden with moral values and they act for the society; hence, they voluntarily take responsibility by assuming an active role for the well-being of all people living in their own society. Being knowledgeable about politics is inherent in these "doers" and in addition to being aware of their up-to-date political environment, they choose to act upon the needs of the society. They are willing to change things for the better and ready to do whatever is necessary. One vital feature is that such citizens believe in democracy and they defend democratic values.

Citizenship education may be defined as a conscious attempt to improve students' knowledge of politics and law and also to encourage them in order to act in their own society. There is clear emphasis on action as a responsible citizen for instructing this kind of education by several authors. The teaching of values and morals is an inseparable component of citizenship education. Students need to be taught to behave constructively in the daily, political life and taking part in this aspect of life must be regarded as a natural way of living.

For some researchers, citizenship education is included among various types of character education. Many scientists agree on the common points that are shared by both character education and citizenship education. For instance, what made them appear is the same: some kind of crisis in the society caused them to be born. Another example is both are effective in educational institutions if a democratic classroom climate can be achieved. One other similarity is that both currents are directly related to values. Community service learning is one shared tool for both of them. Morality is emphasized by both educational currents. Lastly, 
many character virtues are included in both citizenship education and character education.

To conclude, for further research, studies focussing on differences between the two currents may be designed. A different kind of research could be an investigation of citizenship education as well as character education in non-democratic countries. Perhaps a comparison and also contrast of citizenship education in democratic and non-democratic countries might be the topic of another scientific research. Alternatively, the same research findings of a study on citizenship education can be interpreted by educational scientists and political scientists. More possible research subjects could be increased. In terms of research methods, both quantitative and qualitative research methods could be used for the strengthening and verification of research results.

\section{References}

Anderson, D. R. (2000). Character education: Who is responsible? Journal of instructional psychology, 27(3), 139-142.

Arthur, J. (1998). Communitarianism: What are the implications for education? Educational studies, 24(3), 353-368. http://dx.doi.org/10.1080/0305569980240308

Arthur, J., \& Davison, J. (2000). Social literacy and citizenship education in the school $\begin{array}{llll}\text { curriculum. The } & \text { curriculum }\end{array}$ http://dx.doi.org/10.1080/095851700361366

Ayşan, E. (2003). Internet desteğinde bilimsel makale ve tez yazımı. İstanbul, Turkey: Nobel T1p Kitabevleri. p. 134.

Creswell, J. W. (1994). Research design: Qualitative and quantitative approaches. Thousand Oaks, CA: Sage Publications. p. 26.

Davies, I., Gorard, S., \& McGuinn, N. (2005). Citizenship education and character education: Similarities and contrasts. British journal of educational studies, 53(3), 341- 358. http://dx.doi.org/10.1111/j.1467-8527.2005.00299.x

Haynes, C., Leming, J., Groth, J., Lindquist, T., Lockwood, A., Marshall, P., \& Nickell, P. (1997). Fostering civic virtue: Character education in the social studies. Social education, 61(4), 225-227.

Hoge, J. D. (2002). Character education, citizenship education, and the social studies. The social studies, 93(3), 103-108. http://dx.doi.org/10.1080/00377990209599891

Howard, R. W., Berkowitz, M. W., \& Schaeffer, E. F. (2004). Politics of character education. Educational policy, 18(1), 188-215. http://dx.doi.org/10.1177/0895904803260031

McLaughlin, T. H. (2000). Citizenship education in England: The Crick report and beyond. Journal of philosophy of education, 34(4), 541-570. http://dx.doi.org/10.1111/1467-9752.00194 
Milson, A. J., \& Chu, B. (2002). Character education for cyberspace: Developing good $\begin{array}{llll}\text { netizens. The social } & \text { 117-119. }\end{array}$ http://dx.doi.org/10.1080/00377990209599894

Revell, L. (2002). Children's responses to character education. Educational studies, 28(4), 421-431. http://dx.doi.org/10.1080/0305569022000042426

Robson, C. (2000). Real world research: A resource for social scientists and practitioner-researchers. Oxford, England: Blackwell Publishers Inc. p. 288.

Sax, L. J. (2004). Citizenship development and the American college student. New directions for institutional research, 122, 65-80. http://dx.doi.org/10.1002/ir.110

Westheimer, J., \& Kahne, J. (2004). What kind of citizen?: The politics of educating for democracy. American educational research journal, 41(2), 237-269. http://dx.doi.org/10.3102/00028312041002237

\section{Copyright Disclaimer}

Copyright reserved by the author(s).

This article is an open-access article distributed under the terms and conditions of the Creative Commons Attribution license (http://creativecommons.org/licenses/by/3.0/). 